\title{
Development of diversified hand woven furnishing products with amalgamated assamese woven motifs and assessment of consumer preference
}

\author{
Nabaneeta Gogoi, Parishmita Neog and Dibyashree Saikia
}

Received: 03.09.2020; Revised: 25.10.2020; Accepted: 16.11 .2020

See end of the paper for authors' affiliations

\section{Nabaneeta Gogoi}

Department of Textiles and Apparel Designing, College of Community Science, Assam Agricultural University, Jorhat (Assam) India

Email : nabaneetagogoi@gmail. com
DABSTRACT : Handlooms are environment-friendly technology as they require no energy in operation except for the machinery that spins the yarn. The handloom sector plays a strategic role in the upliftment of the rural economy of India, with its attractive products shows dexterity and artistic ability of the weavers. Even today, the rural people of India mostly women grossly depend on the handloom which requires minimum capital and less technical skills. The present study is an attempt to develop diversified hand-woven furnishing products that require less time to produce and can have ever-growing market potentials. Different unique and peculiar products were developed by amalgamated woven designs and products were evaluated to assess the consumer acceptability. The study revealed that design innovation has a tremendous effect on consumer choices. Among the developed designs, design no. 3 and 10 got highest (2.96) WMS followed by design no. 6, 11, 12 (2.92) and design no. 1 (2.90), respectively in different developed products. It was found that a healthy handloom industry requires a broad and varied product range, design intervention, and appropriate marketing mechanisms for higher marketability. Hence, the study can help the weavers of Assam towards a new perspective of value-added products for their sustainable livelihood.

KEY WORDS: Handloom, Traditional, Diversified, Amalgamation, Design, Weaver

- HOW TO CITE THIS PAPER : Gogoi, Nabaneeta, Neog, Parishmita and Saikia, Dibyashree (2020). Development of diversified hand woven furnishing products with amalgamated assamese woven motifs and assessment of consumer preference. Asian J. Home Sci., 15 (2) : 281-288, DOI: 10.15740/HAS/AJHS/ 15.2/281-288. Copyright@ 2020: Hind Agri-Horticultural Society. 